\title{
Genetic Marker Patterns and Endogenous Mammary Tumor Virus Genes in Inbred Mouse Strains of Japan
}

\author{
Shunsuke IMAI, Junji MORIMOTO, Yoshihiko TSUBURA, Kosaburo \\ ESAKI*, Rob MICHALIDES**, Roger S. HOLMES*** \\ Otto von DEIMLING****, and Jo HILGERS** \\ Department of Pathology, Nara Medical College, 840 Shijo-cho, Kashihara-shi, \\ Nara-ken, Japan, *Central Institute for Experimental Animals, 1430 Nogawa, \\ Miyamae-ku, Kawasaki-shi, Kanagawa-ken, **Tumor Biology, The \\ Netherlands Cancer Institute, Plesmanlaan 121, Amsterdam, The \\ Netherlands, ***School of Science, Griffith University, Nathan, \\ Australia and ****Abteilung für Chemische Pathologie, \\ Pathologisches Institut, Universität Freiburg, D-7800 \\ Freiburg, F. R. G.
}

(Received 8 October 1985/Accepted 31 January 1986)

\begin{abstract}
In order to establish the genetic relatedness of the inbred mouse strains kept in Nara, genetic marker patterns were determined in conjunction with a study on endogenous mammary tumor viral genes in these strains. Isoenzyme patterns combined with patterns of other genetic markers, show that the unrelatedness between various inbred strains of the dd stock is as high or even higher as between strains of known different origin and geneology. Based on endogenous viral gene patterns the $\mathrm{dd}$ stock derived mice can be subdivided into three group, (1) DDD, DDN, DDO, (2) KF and (3) DD/ Tbr. The DD/Tbr and its foster-nursed substrain (DD/Tbrf) have the lowest number of endogenous viral genes, i. e. two, while the other strains carry 4-6 such genes.

The SLN and SHN strains, derived from a Swiss stock, have a similar pattern of viral genes different that of all other strains studied, also strains of Swiss origin from other sources, such as the NFS and the GR.
\end{abstract}

Inbred mouse strains are important "tools" to understand the genetic basis for diseases, notably the origin of neoplasms. Their usefulness depends very much on knowledge of their genetic background and characteristics. In order to compare for example tumor incidences in inbred strains between various laboratories, it is inconceivable to date that the genetic marker patterns of the strains would not be known.

Some of the largest inbred mouse colonies in the world, such as those in the Jackson Labs in the USA and the Netherlands Cancer Institute in Amsterdam, have very well defined and genetically characterized inbred strains of diverse origin for genetically oriented research
[24]. The isoenzyme and other genetic marker patterns of these strains are now well known $[23,24,55]$. Some important conclusions of such work is that many mouse strains were separated too early during inbreeding and that residual heterozygosity is an important problem [1], that mutations can occur after decades of separation $[1,23]$ and that endogenous retroviral genes can segregate and get amplified [7].

Since endogenous viral genes, e. g. of the mammary tumor virus, are known to influence spontaneous mammary cancer incidence very dramatically (for review, see $[2,22]$ ). It is self evident that the number and quality of such genes should be determined, if one wants 
to study the mechanisms of mammary tumorigenesis.

In this study we have compared the genetic marker patterns of some widely used inbred strains in Japan, notable of the dd stock, with that of the patterns of endogenous mammary tumor virus. We conclude that differences between the inbred dd strains are much higher than expected. Although these strains represent a quite unique series of useful sublines, they differ widely among each other.

\section{Materials and Methods}

Origin of Mouse Strains (see Figs. 1 and 2) [56]. In 1910, non-inbred albino mice were brought from Germany to Japan by S. Hata, and were raised in the Kitazato Institute, Tokyo. They were transferred to Dairen in 1935 and brought back to the Institute of Infections Diseases (Denken in Japanese abbreviation) in Japan in 1943. The mice were designated as $\mathrm{dd}$ : one $\mathrm{d}$ stands for German (Deutch) origin and the other $d$ stands for Denken (Present designation : Institute for Medical Science).

The DD/Tbr strain has been inbred by Y. Tsubura from this "dd" stock mice. some dd mice were transferred to Osaka University, from where some of them were obtained and inbreeding has been carried out at Nara Medical College (Japan) by Tsubura in order to raise the mammary cancer incidence. This $\mathrm{DD} / \mathrm{Tbr}$ strain is a high mammary cancer strain and reached the 77th inbred generation. The DD/Tbrf strain was foster-nursed on C57BL/6J mice to eliminate it's milk-factor and was designated as DDf.

In 1952, some dd mice were transferred to the Central Institute for Experimental Animals (CIEA) in Tokyo, where they were designated as ddN, $N$ standing for the name of the director (Nomura). Some ddN mice were transferred to Osaka University, where

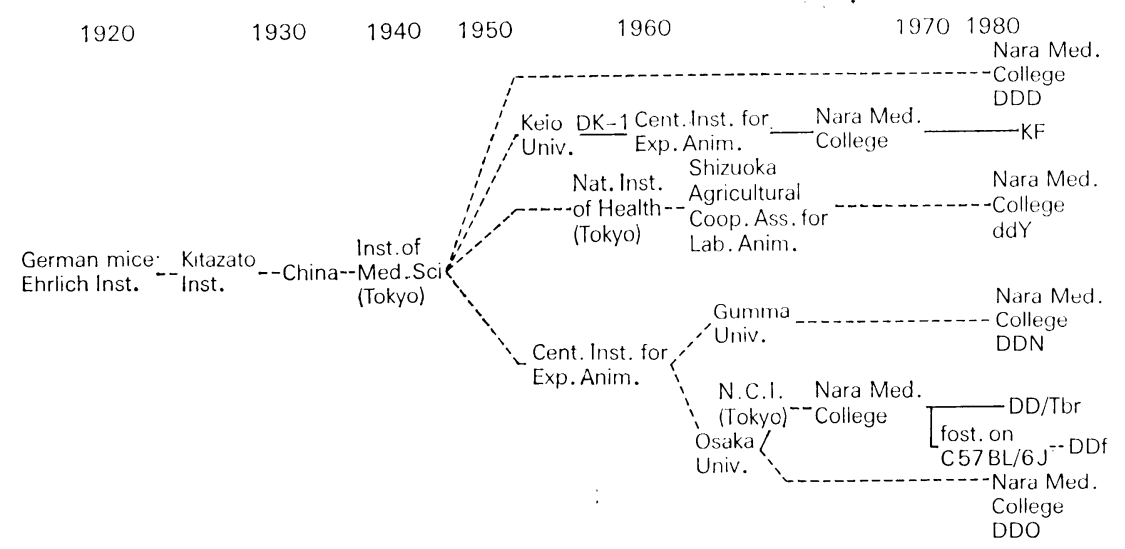

Fig. 1. Family tree of German Mouse Group

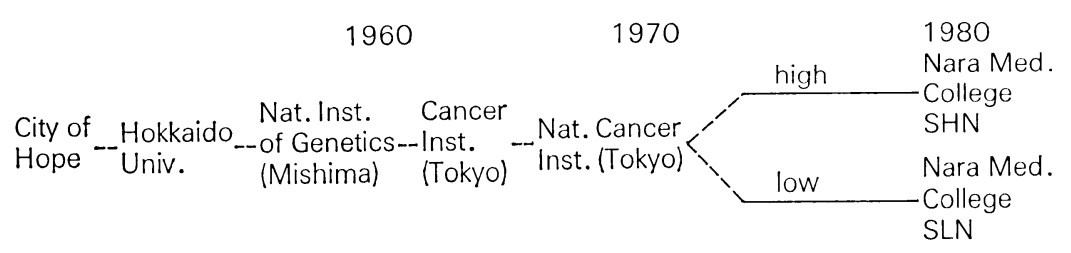

Netherlands
Cancer Inst._. Nat. Cancer Kansai
(A'dam)

Fig. 2. Family tree of Swiss Mouse Group 


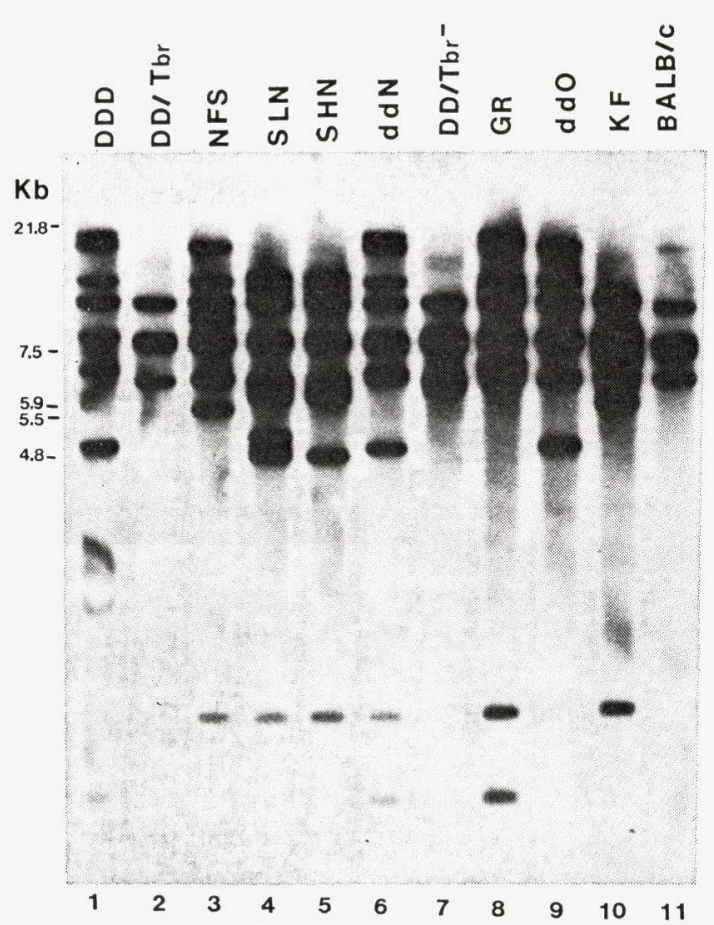

Fig. 1. Detection of MTV DNA sequences in liver DNA of DDD, DD/Tbr, NFS, SLN, SHN, DDN, DDf, GR, DDO, KF and $\mathrm{BALB} / \mathrm{c}$ mice.

they were raised by J. Kawamata, and were designated as $\mathrm{ddO}(\mathrm{O}$ stands for Osaka).

ddN mice were transferred from CIEA to the National Institute of Health (Yoken in Japanese abbreviation) in 1953, where the mice were designated as ddY ( $\mathrm{Y}$ stands for Yoken). In 1963, some ddY mice were transferred to Shizuoka Agriculture Cooperative Association for Laboratory Animals, from which mice were purchased in 1979.

Some ddN mice in the CIEA were transferred to Gumma University, where the inbreeding was carried out and they were obtained from S. Mitsuhashi in 1979.

One dd stock was inbred by B. Kitasato to develop a strain susceptible to Salmonella infection. While maintaining the strain at the CIEA, occasional testicular tumors were observed. Some of them were brought to Nara Medical College in 1963. The strain was designated as KF. Occasional mammary tumors and leukemias were observed but no testicular tumors developed. Inbreeding has reached the 40th inbred generation in Nara.

The DDD strain has been inbred from "dd" stock mice since 1962 at the Institute of Medical Science in Tokyo by K. Suzuki and A. Matsuzawa. Mice of early inbred generations showed a moderately high mammary cancer incidence, though mammary cancer incidence declined in later inbred generations.

The SHN and SLN mice were derived from Swiss albino mice transferred to Japan in 1963 from the City of Hope Medical Center in the U.S. A. The stock was maintained first at the Hokkaido University in Sapporo, and subsequently the National Institute of Genetics in Mishima where it was maintained by pen-matings. Inbreeding was started in 1964 by H. Nagasawa at the National Cancer Research Institute in Tokyo. The SHN and SLN strains were created by inbreeding Swiss mice with continuous selection for high and low mammary cancer incidence. Both strains were obtained from H. Nagasawa in 1978 in the F28 (SHN) and F27 (SLN) generations.

The GR/A (GR) strain has been obtained from S. Morii of Kansai Medical University in 1977. The strain originated in Switzerland and was inbred by Mühlbock in Amsterdam.

$\mathrm{BALB} / \mathrm{cHe}(\mathrm{BALB} / \mathrm{c})$ mice were transferred from Simonson's laboratory in 1920's and some mice were maintained in Taisho Pharmaceutical Co.. They were obtained in 1968 in Nara Medical College.

C57BL/6J (C57BL) mice have been inbred since 1980 by $\mathrm{A}$. Matsuzawa at the Institute of Medical Science in Tokyo.

NFS mice are from a subline of the maintained in the National Institute of Health in the U. S. A. and were obtained in 1980 from A. Ishimoto at the Institute for Virus Research, Kyoto University.

Homogenate preparation-Tissue homogenate from freshly killed mice (10 males and 10 females) were prepared as previously described [28].

Cellulose acetate electrophoresis and staining-Homogenate supernatants were subjected to some electrophoresis on Titan III cellulose acetate plates (Helena Labs, TX) as described 
previously [28].

Esterase assay-Polyacrylamide disc electrophoresis was performed on $7.5 \%$ slab gels using a Tris-glycine buffer system as described [43].

DNA Extraction-Liver was removed from the animals, and stored at $-70^{\circ} \mathrm{C}$. Tissues

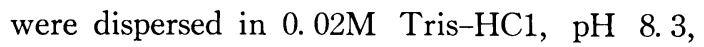
0.01M EDTA, 0.1M NaC1, 0.1\% NP40, using a motor-driven teflon-grass dounce homogenizer. Nuclei were pelleted by centrifugation for $5 \mathrm{~min}$ at $3000 \times \mathrm{g}$. The nuclear pellet was washed three times with $15 \mathrm{ml}$ of homogenization buffer and resuspended in 20 $\mathrm{ml}$ of TNE. Self-digested pronase and SDS were added to $0.2 \mathrm{mg} / \mathrm{ml}$ and $1 \%$ respectively. After incubation for $12 \mathrm{hr}$ at $37^{\circ} \mathrm{C}$ the DNA was extracted with phenol-chloroform and precipitated by the addition of $2 \mathrm{vol}$ of ethanol. The DNA was collected by centrifugation, resuspended in $2 \times \mathrm{SSC}(1 \times \mathrm{SSC}$ is $0.15 \mathrm{M}$ $\mathrm{NaCl}, 0.015 \mathrm{M} \mathrm{Na}$-citrate) and treated with $50 \mu \mathrm{g} / \mathrm{ml}$ ribonuclease A for $2 \mathrm{hr}$ at $37^{\circ} \mathrm{C}$.

The DNA was then again extracted with phenol-chloroform and after precipitation with alcohol resuspended in $1 \mathrm{mM}$ EDTA and stored at $4^{\circ} \mathrm{C}$.

Digestion of DNA with restricton endonucleases, gel electrophoresis, DNA transfer, and hybridization-Restriction enzyme EcoRI was purchased from Boehringer Mannheim Corp. Twenty micrograms of DNA was digested to completion with an excess of enzyme in the appropriate buffer for $12 \mathrm{hr}$ at $37^{\circ} \mathrm{C}$. The extraction of the DNA, gel electrophoresis conditions, DNA transfer, and hybridization with ${ }^{32} \mathrm{P}$-labeled MuMTVcDNA were performed as described previously [39].

\section{Results}

Patterns of markers and details for each of the strains were as follows : Adh-1=Alcohol dehydrogenase $-1 \quad[26,27,30,32,33]$. No variation was observed.

Adh-2=Alcohol dehydrogenase-2 [30].

No variation was observed.

Adh-3= Alcohol dehydrogenase-3 [30, 33]. The uncommon $b$ alleles are present in the DDD and C57BL strain.
Adh-3t $=$ Alcohol dehyrogenase temporal [33]. The uncommon $b$ alleles are found in $\mathrm{KF}, \mathrm{DDD}, \mathrm{DDN}$ and $\mathrm{C} 57 \mathrm{BL}$ strain. Linkage disequilibrium was observed between Adh-3 and Adh-3t in KF and DDN strain only.

Ahd-1 = Aldehyde dehydrogenase -1 [26]. Both alleles are commom.

Ahd-2=Aldehyde dehydrogenase-2 [62]. Only the $a$ allele is observed in all strains.

Ahd $-4=$ Aldehyde dehydrogenase- 4 (stomach) [Mather, P. et al., private communication]. All carried $a$ allele.

Ahd $-5=$ Aldehyde dehydrogenase AHD-5 [Mather, P. et al., private communication]. All carried $a$ allele.

Ahr-1=Aldehyde reductase-1 [16]. The $b$ allele is present only in DDD strain.

Alr-1=Liver aldose reductase [Mather, P. et al., private communication]. All carried $a$ allele.

Alr-2=Liver aldose reductase-2 [Mather, P. et al., private communication]. All carried $a$ allele.

Akp-1=Alkaline phosphatase [24]. The $a$ alleles are present in SHN, SLN and C57BL stain.

Aox $-1=$ Aldehyde oxidase $-1 \quad[27,31,33$, 34]. All strains carried $a$ allele.

Aox $-2=$ Aldehyde oxidase -2 [27, 31, 33, 34]. The $b$ allele are found in SHN and SLN strains only.

Bcd-1 = Butyryl CoA dehydrogenase-1 [58]. Most of the strains carried $a$ allele except for DDD strain.

Car $-2=$ Carbonic anhydrase-2 [17]. The $a$ and $b$ alleles are almost equally divided among the strains except for ddY strain, which showed heterogeneity for $a$ and $b$ alleles.

Dao-1=D-amino acid oxidase [25]. The $\mathrm{DD} / \mathrm{Tbr}$ and DDf strains carried $b$ allele, while most of the other strains carried $a$ allele.

Es-1 $=$ Serum albuminesterase -1 [52, 54]. The rare allele $a$ is present in the C57BL strain only.

Es-2=Serum prealbuminesterase $[48,55]$. carried $b$ allele.

Es-3=Eserine-sensitive erythrocyte esterase, Chr 11 [55], The $a$ allele was found in $\mathrm{BALB} / \mathrm{c}, \mathrm{C} 57 \mathrm{BL}$, and NFS. Strain GR 
carried the $b$ allele whereas the other strains showed the $c$ allele.

Es-5=Slowly migrating serum esterase, Chr 8 , cluster 2 [49]. The null allele $a$ was found in DDD and in DDN only.

Es-6=Ubiquitous carboxylesterase, first discovered in kidney. Chr 8, cluster 1 [40, 50]. No variation was found.

Es-7=Erythrocyte membrane carboxylesterase, $\mathrm{Chr} 8$, cluster $2[5,43]$. No variation was found.

Es-9 $=$ Sex dependent kidney carboxylesterase, Chr 8, cluster 1 [57]. No variation was found.

Es-10 = Dimeric erythrocyte esterase, Chr $14[46,63]$. The $a$ and $b$ alleles were almost equally distributed.

Es-11=Liver carboxyl esterase, $\mathrm{Chr} 8$, cluster 2 [47]. The strains DDD and DDN carried the $b$ allele. The other strains showed the more common $a$ allele.

Es-13=A modifying locus, probably originating from mice of Switzerland, Chr 9 [64]. The unusual $b$ allele was found in four strains : DD/Tbr, DDf, SHN, and NFS.

Es-14= Tetrameric erythrocyte esterase, Chr $9[3,4]$ All strains carried the allele $r$ common in the European subspecies M. m. domesticus.

Es-16 = Particle bound kidney arylesterase, Chr 3 [9]. All strains carried the common allele $a$.

Es-17=Acetylesterase, Chr 9 [45]. All strains carried the common allele $a$.

Es-18=The structural locus of that esterase which is modified by $E s-13$ [8]. No variation was found.

Es-22=Liver carboxylesterase, Chr 8, cluster 1 [18]. All strains carried the common $a$ allele.

Es-23=Kidney carboxylesterase, $\mathrm{Chr} 8$, cluster 2 [12]. All strains carried the $c$ allele.

Es-24=Phenotype designation. Es-24 is a highly polymorphic, polymeric lung carboxylesterase, probably heteromeric. No separate gene locus was proposed until now. Chr 8, cluster 1 [10]. Strain KF showed the $24 \mathrm{~F}$ phenotype.

Es-25=Water soluble kidney arylesterase, gene locus unknown [11]. Three strains, DDD,
$\mathrm{DDN}$, and BALB/c carried the $a$ allele. Es-26=Liver cholinesterase, $\mathrm{Chr} 3$ [13]. Three strains, DD/Tbr, DDf and DDO carried the $b$ allele. The other strains showed the $a$ allele.

Gpd $-1=$ Glucose phosphate dehydrogenase -1 [56]. The $b$ allele is found in the SLN, NFS and C57BL strains, while most of other strains carried $a$ allele.

Gpi-1=Glucose phosphate isomerase-1 [14]. The $b$ allele is found in the SLN, NFS and C57BL strains, while most of other strains carried $a$ allele.

Hao- $1=$ Alpha-hydroxyacid oxidase- $1[15$, 35]. No variation was found.

$\mathrm{Hbb}=$ Hemoglobin beta-chain [51]. Both $d$ and $s$ allele are present.

$\mathrm{Hc}=$ Hemolytic complement. Strain with 1 allele have the C5 complement protein, while strain with the 0 allele lack the protein [6].

$\mathrm{H}-2=$ Histocompatibility -2 [38].

Idh-1 = Isocitrate dehyrogenase- 1 [20]. Both $a$ allele are present.

Ldr $-1=$ Lactate dehydrogenase regulator -1 [59]. The rare $o$ allele is found in the NFS strain only.

Mod-1 $=$ Malic enzyme, supernatant [21]. The $a$ and $b$ alleles are almost equally divided among the various strains.

Mpi-1 = Mannose phosphate isomerase-1 [41]. All strains carried $b$ allele.

Mup-1= Major urinary protein [19]. Most of the strains carried $a$ allele except for C57 BL strains.

Pep-3=Peptidase-3 (formerly Dip-1) [42]. The rare $c$ allele is found in the $\mathrm{DD} / \mathrm{Tbr}$, DDf and DDO strain. The $a$ allele is present in the $\mathrm{BALB} / \mathrm{c}$ and $\mathrm{C} 57 \mathrm{BL}$ strains.

Pgm-1 = Phosphoglucomutase-1 [60]. Both $a$ and $b$ allele are present.

Sdh- $1=$ Sorbitol dehydrogenase- 1 [14, 28]. All strains have $a$ allele.

Thy- $1=$ Thymus cell antigen- 1 (theta) [23]. All strains carried $b$ allele.

$\operatorname{Trf}=$ Transferrin [61]. All strains carried $b$ allele.

The inbred strains kept in Nara can be divided in four groups according to their origin : 1. The group of the "dd" stock mice, 


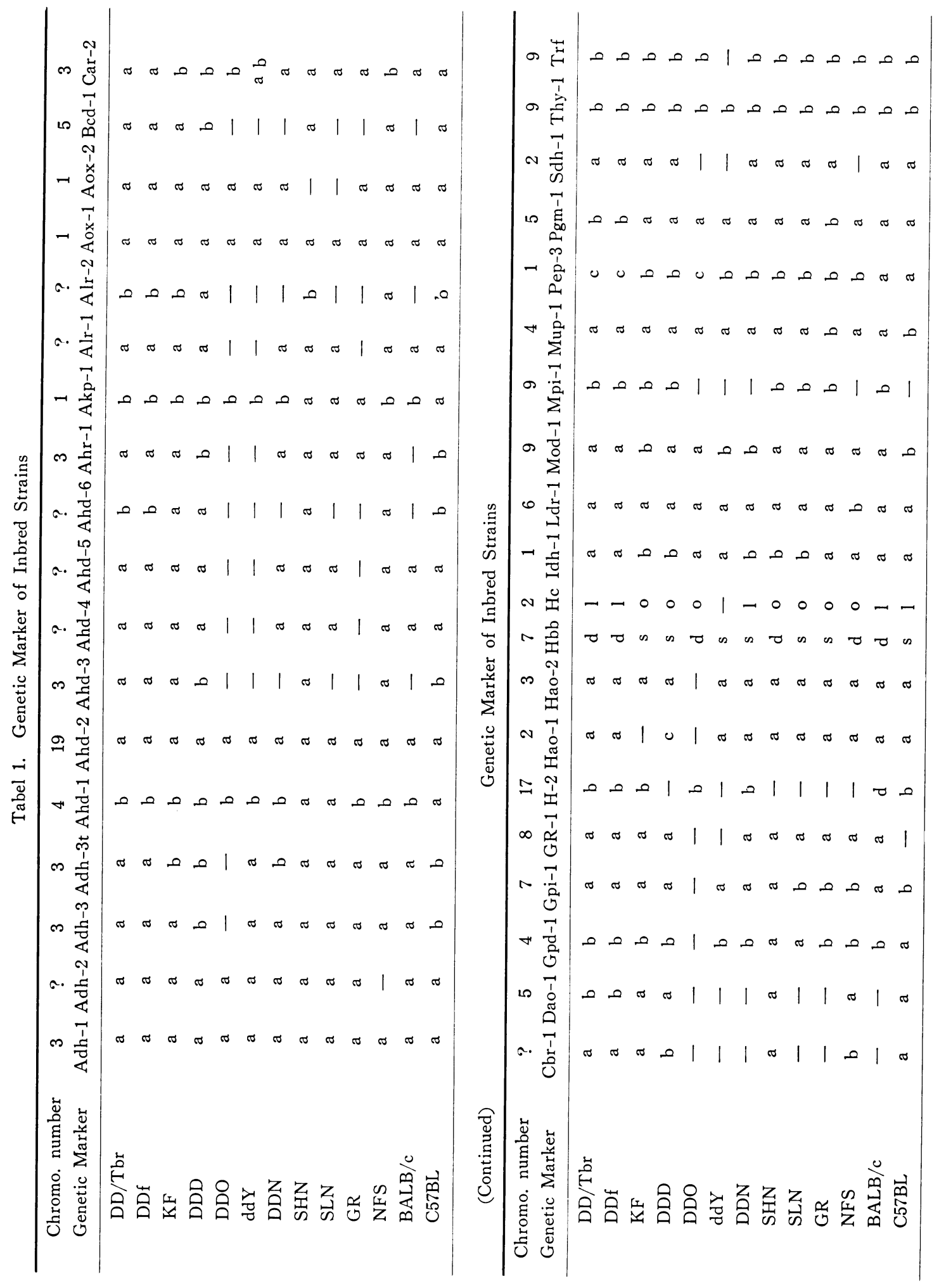




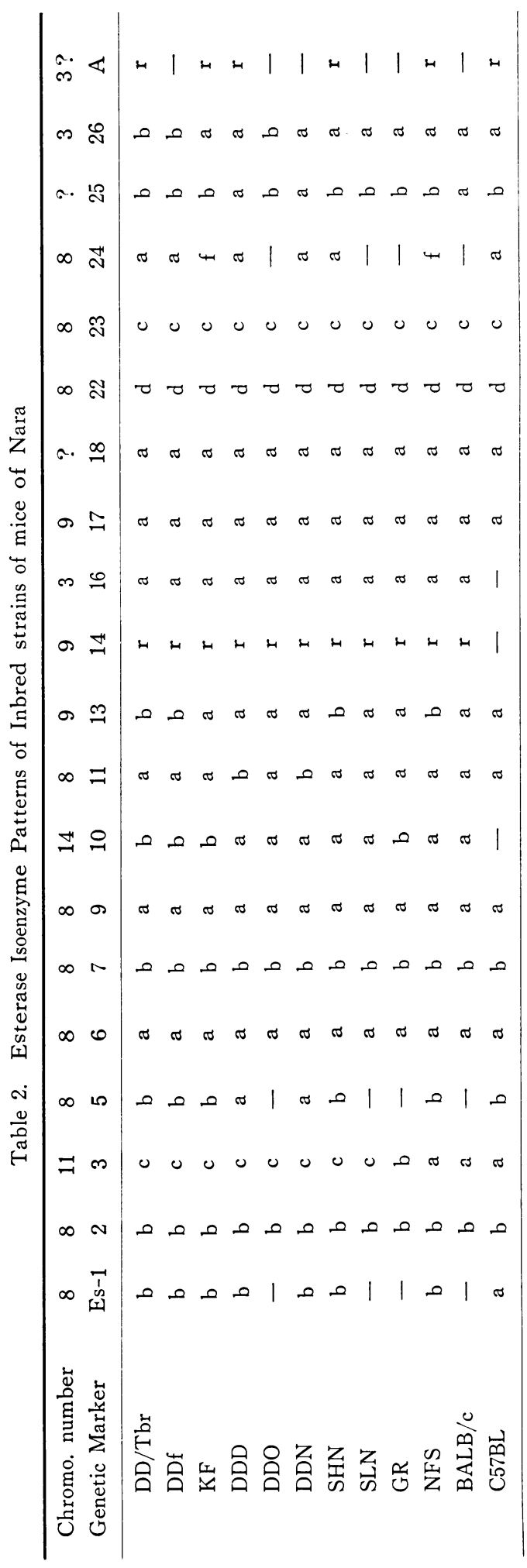

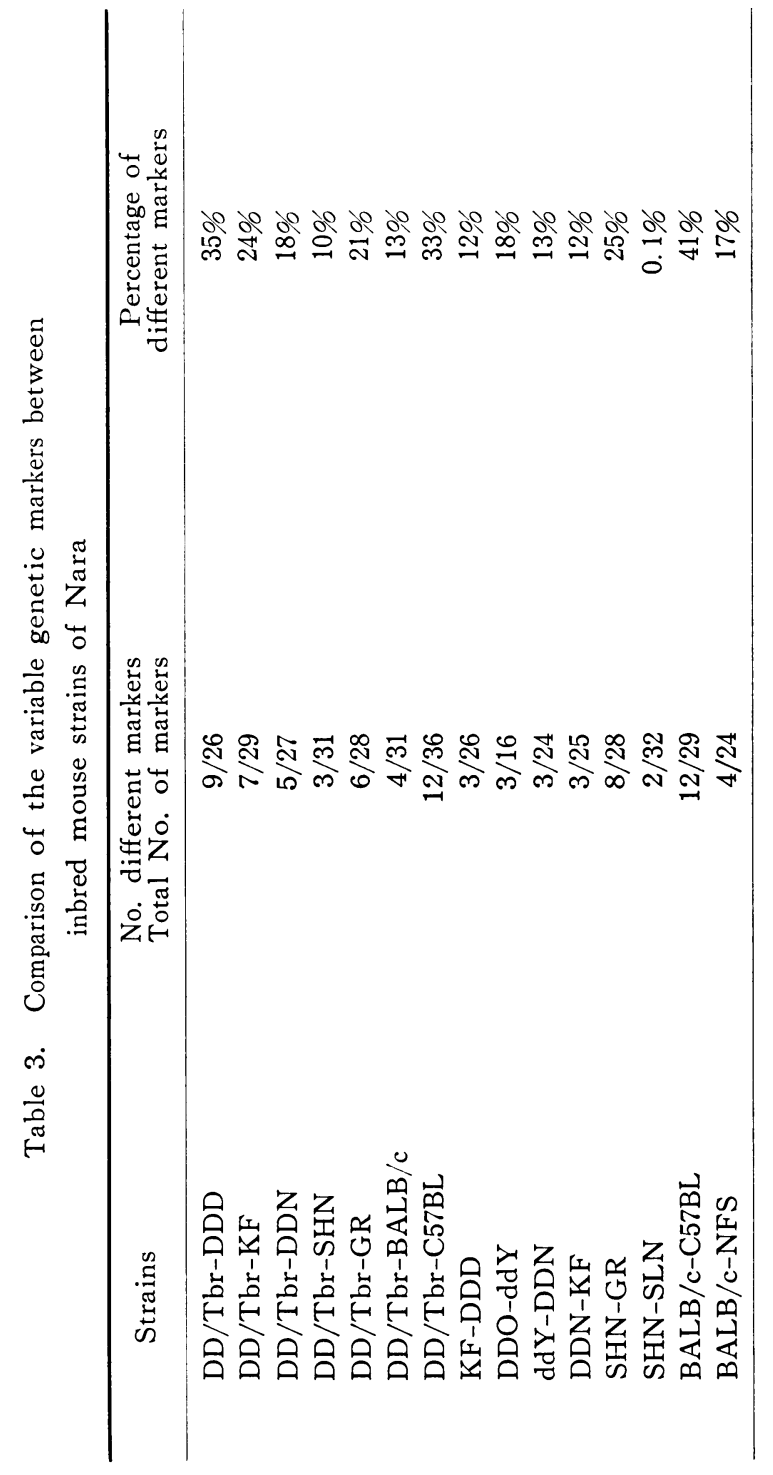


including $\mathrm{DD} / \mathrm{Tbr}, \mathrm{DD} / \mathrm{Tbrf}, \mathrm{KF}, \mathrm{DDD}$ $\mathrm{DDO}$, ddY and DDN. 2. The group of mice of Swiss origin, including SHN, SLN, GR and NFS. 3. One strain of American origin: $\mathrm{BALB} / \mathrm{c}$. 4. A second strain of American origin : C57BL.

Inbreeding of these mice was done mainly in Japan, except for the GR, NFS, BALB/c and C57BL strains. The geneology of the strains inbred in Japan is given in Figs. 1, 2. The mice of the random bred "dd" stock were inbred in quite a number of different Japanese laboratories from the late 1940. The SHN and SLN strains were inbred from a random bred Swiss stock with simultaneous selection for high mammary cancer incidence.

Tables 1,2 shows the results of a survey for genetic markers, mainly isoenzymes, in these strains. The patterns of the GR, C57BL and $\mathrm{BALB} / \mathrm{c}$ strains are identical to those of these strains in the Amsterdam colony [23], National Cancer Institute [24] and the Jackson Laboratories [54]. The NFS strain is relatively unknown in this respect and shows a unique marker pattern. The SHN and SLN strains are very similar: $30 / 32$ marker are identical (see also Table 3 for comparison of strains).

The mice of the "dd" stocks are, however, quite different from each other and one wonders whether genetic, unrelated to that of this stock, has been crossed into some of these strains. The differences ranges from $12 \%$ to 35 \%o (between DD/Tbr and DDD). If one compares this with the $41, \%$ difference in these markers between $\mathrm{BALB} / \mathrm{c}$ and $\mathrm{C} 57 \mathrm{BL}$, two totally unrelated strains, it is clear that the various inbred strains from the "dd" stocks are not related at all, though it appears that two strains DDD and DDN are quite identical in esterase patterns.

This view is substantiated by the patterns of endogenous mammary tumor virus genes as shown in Figure 3. Within the "dd" group, the patterns of the DDD, DDN and DDO resemble each other very much, but this pattern is very different from that of the KF strain and also of the $\mathrm{DD} / \mathrm{Tbr}$ and $\mathrm{DD} / \mathrm{Tbrf}$ strains. The latter strain has very few endogenous MTV genes (not more than two), even fewer that the $\mathrm{BALB} / \mathrm{c}$ strain. The other dd stock mice may have 4-6 endogenous viral genes, because EcoRI cuts the MTV genome in 2 fragments.

The patterns of the SHN strains are very similar, with one or two more bands in the SLN. Both strains have a high and early mammary tumor incidence. In case of the SHN strain this is due to the Mtv-4 locus [37].

The NFS pattern of viral genes looks like that of the GR, though the tumor incidence is very low.

\section{Discussion}

The results presented here clearly show that the various inbred strains derived from the wellknown "dd" stock are occasionally as much different from each other as totally unrelated strains of American and European origin. If one considers endogenous MTV gene patterns as a good parameter for relatedness, one could classify the strains of Nara into three categories: 1 . Group $1: \mathrm{DDD}, \mathrm{DDN}$, DDO (and perhaps ddY), 2. Group $2: \mathrm{KF}$, 3. Group $3: \mathrm{DD} / \mathrm{Tbr}$ strain and its fosternursed substrain $\mathrm{DD} /$ Tbrf.

However, this distinction is less clear if one considers the isoenzyme patterns, because few of these markers are characteristic for one of the three groups. One could say that the Pgm- $1^{\mathrm{b}}$ marker is typical for the DD/Tbr strains as opposed to the other strains in group 1 and 2, but one cannot find markers indicative of the other groups only.

If the two genes of endogenous MTV of the $\mathrm{DD} / \mathrm{Tbr}$ stock represent the common ancestor genes of this virus in the "dd" stock mice, it follows that the additional genes of the other strains, notably of group 1, are recent reintegrations which occurred in the past 30 years. However, the endogenous genes of the dd stock are known not to get expressed at all [36] and it is therefore hard to speculate that they are the genes which would be amplified in the other stocks. Since it is hardly conceivable that the DD/Tbr stock lost endogenous MTV genes as compared to the strains of group 1, it follows that some of these endogenous viral genes were introduced 
by other genetic material, e. g. from mice of Swiss stock origin or other unknown origin. This speculation is not wholly unwarranted because of the similarities in several endogenous viral gene sizes of the Swiss stock and dd stock strains.

This could also be deduced from some of the marker patterns. The rare $\mathrm{Hbb}^{\mathrm{s}}$ gene, e. g. is present in Nagasawa's SLN stocks is also observed in some dd stock mice. Recently Yonekawa et al. also [65] showed that a closed colony ddY has a mixture of domesticus and molossinus mitochondrial DNAs suggesting that the original $\mathrm{dd}$ stock was contaminated with another mice of different origin. It should be emphasized, however, that more extensive studies on genetic marker patterns of Japanese inbred strains are necessary to understand the genetic relationships between these strains as they occur now. For the mice kept at Nara such studies are being planned and executed.

This work was supported in part by Grants-in-Aid for Cancer Research 4010410 and 4010411 from the Ministry of Education, Science and Culture, Japan.

\section{References}

[1] Bailey, D. W. (1978). Sources of subline divergence and their relative importance for subline of six major inbred strains of mice. In Origin of Inbred Mice pp 197-215., H. C. Morse (edit.), Academic Press, New York.

[2] Bentvelzen, P., and Hilgers, J. (1980). Murine mammary tumor virus. In Viral Oncology, pp 311-355 G. Klein (edit.), Raven Press, New York.

[3] Bonhomm, F., Benmehdi, F., Britton-Davidian, J., and Martin, S. (1979). Analyse genetique de croisement interspecitiques Mus musculus $\mathrm{L}$ et Mus spretus Lacaste: Liaison de Adh-1 avec Amy-1 sur le chromosome 3 et de Es-14 avec Mod-1 sur le chromosome 9. C R Acat Sci Ser D, 289, 545 .

[4] Britton-Davidian, and Bonhomm, F. (1979). Deux nouveaux locus d'esterase Es-14 et Es-15 chez les Souris (genre Mus L.): Caracterisation par differencts substrats et inhibiteurs. C $R$ Acad Sci Ser D, 288, 1419.

[5] Chapman, V. (1973). Private communication. Mouse Nezes Letter, 48, 45.

[6] Cinader, B., Dubiski, S., and Wardlaw, A. C. (1964). Distribution inheritance, and properties of an antigen, $\mathrm{mu} / \mathrm{BI}$, and its relation to hemoly. tic complement. J. Exp. Med., 120, 897-924.

[ 7 ] Cohen, J. C., and Varmus, H. E. (1979). Endo- genous mammary tumor virus DNA varies among wild mice and segregates during inbreeding. Nature, 278, 418-423.

[8] Deimling, O. V. (1981). Private commnuication. Mouse News Letter, 65, 13.

[9] Deimling, O. V., Schupp, P., and Otto, J. (1981). Esterase-16 (Es-16): Characterization, polymorphi$\mathrm{sm}$ and linkage to chromosome 3 of a kidney esterase locus of the house mouse. Biochem. Genet, 19, 1091.

[10] Deimling, O. V. (1982). Private communication. Mouse Nezes Letter, 67, 16.

[11] Deimling, O. V. (1983). Private communication. Mouse News Letter. 69, 20.

[12] Deimling, O. V. (1984). Esterase-23 (Es-23): Characterization of a new carboxylesterase isozyme (Ec 3.1.1.1) of the house mouse, genetically linked to Es-2 on Chromosome 8. Biochem. Genet. 22, 767-780.

[13] Deimling, O. V., Wassmer, B., and Muller, M. (1984). Esterase-26( Es-26): Characterization and genetic location on chromosome 3 of an eserine sensitive esterase of the house mouse (Mus Musclus). Biochem. Genet., 22, 1119-1126

[14] De Lorezo, R. J., and Ruddle, F. H. (1969). Genetic control of two electrophoretic variation of glucose-phosphateisomerase in the mouse. Biochem. Genet., 3, 151.

[15] Duley, J., and Holmes, R. S. (1974). Alphahydroxyacid oxidase genetics in the mouse: Evidence for two genetic loci and a tetrameric subunit structure for the liver isozyme. Genetics, 76, 93-97.

[16] Duley, J., and Holmes, R. S. (1982). Biochemical genetics of aldehyde reductase in the mouse: Ahr-1-A new locus linked to the alcohol dehydrogenase gene complex on chromosome 3. Biochem, Genet., 20, 1067-1083.

[17] Eicher, E. M., Stein, R. H., Womack, J. E., Davission, M. T., Roderick, T. H., and Reynolds, S. C. (1976). Evolution of mammalian carbonic anhydrase loci by tandem dupulication: close linkage of Car-1 and Car-2 to the centromere region of chromosome 3 of the mouse. Biochem. Genet., 14, 651-660.

[18] Eisenhardt, E., and Deimling, O. V. (1982). Interstrain variation of esterse-22, A new isozyme of the house mouse. Com. Biochem. Physiol., 73B, 719-724.

[19] Finlyson, J. S., Asofsky, R., Potter, M., and Runner, C. C. (1964). Major urinary protein complex of normal mice: Origin. Science, 194, 981-982.

[20] Henderson, N, S. (1965). Isozymes of isocitrate dehydrogenase: subunit structure and intracellular location. J. Exp. Zool, 158, 263-273.

[21] Henderson, N. S. (1966). Isozymes and genetic control of NADP malate dehydrogenase in mice. Arch Biochem. Biophys, 117, 28-33.

[22] Hilgers, J., and Bentvelzen, P. (1978). Interaction between viral and genetic factors in murine mammary cancer. Adv. Cancer Res., 26, 143-195.

[23] Hilkens, J., Hilgers, J., Demant, P., Michalides, R., Ruddle, F., Nichols, E., Holmes, R., Van 
Nie, R., VandeBerg, J. L., and Nikkels, R. (1981). Origin of and genetic relationships between the inbred mouse strains maintained at the Netherlands Cancer Institute. In Mammary tumor in the mouse., pp 11-44, J. Hilgers and $M$. Sluyser (edit.), Elsevier North-Holland Biomedical Press.

[24] Hoffman, H., Smith, K. T., Crowell, J. S., Nomura, T., and Tomita, T. (1980). Genetic quality control of laboratory animals with emphasis on genetic monitoring. The Symposium of ICLAS 1979. Gustav Fischer Verlage Stuttgart New York 1980.

[25] Holmes, R. S. (1976). Genetics of peroxisomal enzymes in the mouse: Nonlinkage of $\mathrm{D}$-amino acid oxidase locus (Dao) to catalase (Cs) and L-a-hydroxyacid oxidase (Hao-1) loci on chromosome 2. Biochem. Genet., 14, 981-987.

[26] Holmes, R. S. (1978). Genetics and ontogeny of aldehyde dehydrogenase isozymes in the mouse: Localization of Ahd-1 encoding the mitochondrial isozyme on chromosome 4. Biochem. Genet., 16, 1207-1218.

[27] Holmes, R. S. (1978). Genetics of hydroxyacid oxidase isozymes in the mouse: Localization of Hao-2 on linkage group XVI. Heredity (London), 41, 403-406.

[28] Holmes, R. S. (1978). Electrophoretic analysis of alcohol dehydrogenase, aldehyde dehydrogenase, aldehyde oxidase, sorbital dehydrogenase and xanthine oxidase from mouse tissues. Comp. Biochem. Physiol., 61B, 339-346.

[29] Holmes, R. S., Jones, J. T., and Peters, J. (1978). Genetic variation, cellular distribution and ontogeny of sorbitol dehydrogenase and alcohol dehydrogenase isozymes in male reproductive tissues of the mouse. J. Exp. Zool, 206, 279288.

[30] Holmes, R. S. (1979). Genetics and ontogeny of alcohol dehydrogenase isoenzyme in the mouse: Evidence for a cisacting regulator gene (Adt-1) controlling $\mathrm{C} 2$ isozyme expression in reproductive tissues and close linkage of Adh-3 and Adt-1 on chromosome 3. Biochem. Genet., 17, 461-472.

[31] Holmes, R. S. (1979). Genetics, ontogeny and testosteron inducibility of aldehyde oxidase isozymes in the mouse: Evidence for two genetic loci (Aox-1 and Aox-2) closely linking on chromosome 1. Biochem. Genet., 17, 517-527.

[32] Holmes, R. S., Albanese, R., Whitehead, F. D., and Duley, J. A. (1981). Mouse alcohol dehydrogenase isozymes: Producs of closely localized duplicated genes exhibiting divergent kinetic properties. J. Exp. Zool, 217, 151-157.

[33] Holmes, R. S., Andreus, S. T., and Beechey, C. V. (1981). Genetic regulation of alcohol dehydrogenase $\mathrm{C} 2$ in the mouse. Development consequences of the temporal locus (Adh-3t) and positioning of Adh-3 chromosome 3. Derelop Genet., 2, 89-98.

[34] Holmes, R. S., Leijten, L. R., and Duley, J. A. (1981). Liver aldehyde oxidase and xanthine oxidase genetics in the mouse. Anim. Bl. Gps. Biochem. Genet., 12, 193-199.
[35] Holmes, R. S., Duley, J. A., and Hilgers, J. (1982). Sorbitol dehydrogenase genetics in the mouse: A 'null' mutant in a 'European' C57BL strain. Anim. Bl. Gps. Biochem. Genet., 13, 263 272.

[36] Imai, S., Morimoto, J., Tsubura, Y., Iwai, Y., Okumoto, M., Takamori, Y., Tsubura, A., and Hilgers, J. (1983). Tissue and organ distribution of mammary tumor virus antigen in low and high mammary cancer strain mice. Eur. J. Cancer Clin. Oncol. 19, 1011-1019.

[37] Imai, S., Tsubura, Y., Hilgers, J., and Michalides, R. (1983). A new locus (Mtv-4) for endogenous mammary tumor virus expression and early mammary tumor deveropment in the SHN mouse strain. J. Natl. Cancer Inst., 71, 517-521.

[38] Klein J., Flaherty, L., VandeBerg, J. L., and Shrettler, D. C. (1978). H-2 haplotypes, genes, regions and antigens : First listing. Immunogenet, 6. $489-512$.

[39] Michalides, R., Van, Nie, R., Nusse, R., Hynes, N. E., and Groner, B. (1981). Mammary tumor induction loci in GR and DBAf mice contain one provirus of the mouse mammary tumor virus. Cell, 23, 165-173.

[40] Nash, H. R., and Deimling, O. V. (1982) Kidney esterase of Mus Musculus: Further polymorphism of esterase-6, esterase-9. and a new esterase-20. Biochem. Genet., 20, 537-554.

[41] Nichols, E A., Chapman, V. M., and Ruddle, F. H. (1973). Polymorphism and linkage for mannosephosphate isomerase in Mus musculus. Biochem. Genet., 8, 47-53.

[42] Lewis, W. H., and Truslove, G. M. (1919). Electrophoretic heterogeneity of mouse erythocyte peptidases. Biochem. Genet., 3, 439-498.

[43] Lipps, A., Ronai, A., and Deimling, O. V. (1979) Esterase-7, a common constituent of numerous mouse tissues. Comp. Biochem. Phy. siol. 62B, 201-206.

[44] Maurer, H. R. (1971). Disc Elektrophoresis, W. de Gruyter (edit.), Berlin-New York.

[45] Otto, J., and Deimling, O. V. (1983). Esterase17 (Es-17): Characterization and linkage to chromosome 9 of a new bis-p-nitrophenyl phosphate resistant esterase of the house mouse (Mus musculus). Biochem. Genet., 21, 37-48.

[46] Peters, J., and Nash, H. R. (1976). Polymorphism of esterase-10 in Mus musculus. Biochem. Genet., 14, 119-125.

[47] Peters, J., and Nash, H. R. (1977). Polymorphism of esteras 11 in Mus musculus, a further esterase locus on chromosome 8. Biochem. Genet., 15, 217-226.

[48] Petras M. L . (1963). Genetic control of a serum component in Mus musculus. Proc. Natl. Acad. Sci. USA, 51, 112-116.

[49] Petras, M. L., and Biddle, F. G. (1976). Serum esterase in the house mouse, Mus musculus. Can. J. Genet. Cytol., 9, 710-714,

[50] Petras, M. L., and Sinclair, P. (1969). Another esterase variant in the kidney of the house mouse, Mus musculus. Can. J. Genet. Cytol., 11, 97-102.

[51] Popp, R. A. (1965). Hemoglobin variants in 
mice. Fed. Proc., 24, 1252-1257.

[52] Popp, R. A. (1965). Loci linkage of serum esterase patterns and oligosyndactyly. J. Hered, 56, 107-108.

[53] Popp, R. A., and Popp, D. M. (1963). Inheritance of serum esterase having different electrophoretic patterns. J. Hered, 53, 111-114.

[54] Roderick, T. H., Staats, J., and Womack, J. E. (1981). Strain distribution of polymorphic variants. In Genetic variant and strains on the laboratory mouse., pp 369-377. MC Green(edit.), Gustav Fischer Verlag.

[55] Ruddle, F. H., and Roderick, T. (1965). The genetic control of three kidney esterase in C57BL/ $6 \mathrm{~J}$ and RF mice. Genetics, 51, 445-454.

[56] Ruddle, F. H., Shows, T. B., and Roderick, T. H. (1968). Autosomal control of an electrophoretic variant of glucose-6-phosphate dehyrogerase in the mouse (Mus muculus). Genetics, 58, 599-606.

[57] Schollen, J., Bender, K., and Deimling, O. V. (1975). Esterase XXI. Es 9, a possible new polymorphic esterase in Mus musculus genetically linked to Es-2. Biochem. Genet., 13, 369-377.

[58] Seelay, T.L., and Holmes, R. S. (1981). Genetics and ontogeny butyryl CoA dehydrogenase in the mouse and linkage of Bcd-1 with Dao-1. Biochem. Genet., 19, 333-345.

[59] Shows, T. B., and Ruddle, F. H. (1968). Function of the lactate dehydrogenase $B$ gene in mouse erythrocytes : Evidence for control by regu- latory gene. Proc. Natl. Acad. Sci. USA, 61, $574-581$.

[60] Shows, T. B., Ruddle, F. H., and Roderick, T. H. (1969). Phosphoglucomutage electorophoretic variants in the mouse. Biochem. Genet., 3, 25.

[61] Shreffler, I). C., and Owen, R. D. (1963). A serologically detected variants in the mouse serum: Inheritence and association with histcompatibility-2 locus. Genetics, 48, 9-25.

[62] Timms, G, P., and Holmes, R. S. (1981). Genetics of aldehyde dehydrogenase isoenzyme in the mouse : Evidence for multiple loci and localization of Ahd-2 on chromosome 19. Genetics, 97, 327336.

[63] Womack, J. E., and Sharp, M. S, (1976). Comparative autosomal linkage in mammals: Genetics of esterases in Mus musculus and Rattus norvegicus. Genetics, 82, 665-675.

[64] Womack, J. E., Taylor, B. A., and Barton, J E. (1978). Esterase 13, a new mouse esterase locus with recessive expression and its genetic location on chromosome 9. Biochem. Genet., 16, 1107-1112.

[65] Yonekawa, H., Moriwaki, K., Gotoh, O., Miyashita, N., Migita, S, Bonhomme, F., Hjorth, J. P., Petras, M. L., and Tagashira, Y. (1982).

Origins of laboratory mice deduced from restriction patterns of mitochondrial DNA. Defferentiation, 22, 222-226.

\section{我国で系統維持されている近交系マウスに拈ける$$
\text { 遺伝子マーカーと内因性乳癌ウイルスについて }
$$

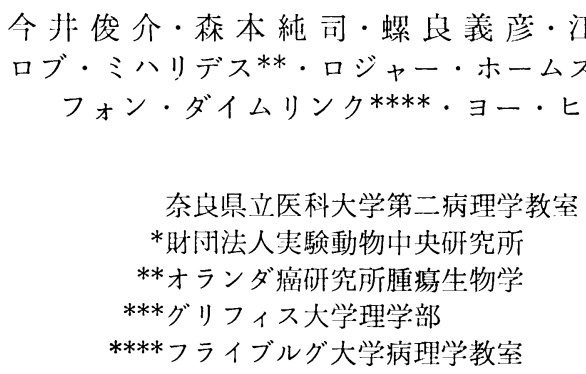

主として奈良医大で維持されている dd 系マウスをは じめ, 近交系マウスの遺伝的背景を明確にするために, 遗伝子マーカおよび内因性乳癌ウイルス（M V V) の動 態について調べた。アイソザイムを中心に他の遺伝子 マーカとの組み合わせの結果, 共通の祖先を有する dd マウス群に抢いても，それぞれのマウスにより遺伝的 に異なる点が明らかになった。またその幅は，dd 系と はまったく異なった由来のマウス系より大きい。内因 性:MTVのDNAへの組み込みの分们でみるとき, dd
系は次の群に分けられる。すなわち，1）DDD, DDN, DDO 2) $\mathrm{KF}$, 3) DD/Tbr である。特に DD/Tbr 系と その外因性M T Vを除去した DD/Tbrf 系のMTVの ゲノムは他の系統と比較して最も少ない。一方，スイ ス由来のS HN系および SLN 系では互いによく似た ゲノムの分布を示すが，NF S 系，GR系のスイス由 来を含め他のすべての系とは，まったく異なった分布 を示した。 